\title{
HIGH MOUNTAIN KARREN IN NORTHWESTERN YUNNAN, CHINA
}

\author{
VISOKOGORSKE ŠKRAPLJE V SEVEROZAHODNEM YUNNANU, \\ KITAJSKA
}

Martin KNEZ ${ }^{1}$, Hong LIU $^{2}$ \& Tadej SLABE ${ }^{1}$

\begin{abstract}
UDC 551.435.1(510

Martin Knez, Hong Liu \& Tadej Slabe: High Mountain Karren in Northwestern Yunnan, China

The high mountain karren rock relief reveals the manner of the formation of the mountain karst surface in the northwestern part of Yunnan at altitudes between 4,000 and 4,600 m. Two dominant factors, snow and rain, decisively influence the formation of the majority of rock forms; in places, particularly on the Shika Snow Mountain, two additional factors are subsoil corrosion and water trickling from overgrown surfaces. Biocorrosion is important for the fine dissection of the rock.

Sub-snow rock forms dominate in places where the rock has been covered by snow for a longer period. These are primarily the gently sloping sunless parts of the karren, the lower parts or lower walls of karren, and fissures. Gently sloping sunless parts of the karren are often dissected in various ways so there are sub-snow forms on their lower parts and rock forms carved by rainwater on the higher parts, peaks, and ridges. Rain rock forms dominate on sunny surfaces and parts of the rock that are steep, located higher above the floor, and covered by only a thin layer of snow.

The relief and individual rock forms are also influenced by the fissuring and the recrystallization of rock characteristic of the Shika Snow Mountain. The rock masses on the Yulong Snow Mountain are larger and its rock forms have more regular shapes. On the Shika Snow Mountain, rock recrystallization has an important influence on the rock forms, causing fine diversities and often jagged edges of rock forms. By this feature of rock forms and the frequent and originally subsoil rock formation on the Shika Snow Mountain we can distinguish the two described areas of mountain karren.

In both mountain areas, the basic characteristics are the same and unique. The rock relief of the mountain karren described in this paper is predominantly dictated by the wider climate
\end{abstract}

\author{
Izvleček \\ UDK 551.435.1(510 \\ Martin Knez, Hong Liu \& Tadej Slabe: Visokogorske škraplje \\ $v$ severozahodnem Yunnanu, Kitajska
}

Skalni relief visokogorskih škrapelj nam razkriva način oblikovanja površja gorskega krasa $\mathrm{v}$ severozahodnem delu Yunnana na nadmorskih višinah med 4000 do 4600 metri. $\mathrm{Na}$ oblikovanje večine večjih skalnih oblik odločilno vplivata prevladujoča dejavnika, sneg in dež, ponekod, še zlasti na snežni gori Shika še podtalna korozija in iztekanje vode s poraščenih površin. Za drobno razgradnjo skale je pomembno biokorozijsko razjedanje.

Podsnežne skalne oblike prevladujejo na mestih, kjer je skala dlje časa prekrita s snegom. To so predvsem položnejši osojni deli škrapelj, nižji deli oziroma nižje stene škrapelj in špranje. Tudi prvi so pogosto raznovrstno razčlenjeni, tako so na njihovih nižjih delih podsnežne oblike, na višjih delih, na vrhovih in grebenih skal, pa skalne oblike, ki jih dolbe deževnica. Dežne skalne oblike prevladujejo na prisojnih površinah in na delih skale, ki jih prekrije le tanjša plast snega torej strmih višje nad tlemi.

$\mathrm{Na}$ skalni relief in na posamezne skalne oblike vplivata tudi razpokanost in prekristaljenost kamnine, ki sta značilnost snežne gore Shika. Skalne gmote na Snežni gori žadastega zmaja (Yulong) so večje, skalne oblike pa pravilnejših oblik. Na snežni gori Shika na skalne oblike pomembno vpliva prekristaljenost kamnine, ki botruje drobnim raznolikostim in pogosto nazobčanim robovom skalnih oblik. Po tem in pogostem, sprva podtalnim oblikovanjem skale na snežni gori Shika lahko razlikujemo opisani vrsti škrapelj.

Temeljne značilnosti pa so $\mathrm{v}$ obeh primerih enake in svojevrstne. Značilni skalni relief tokrat predstavljenih gorskih škrapelj prevladujoče narekujejo predvsem širše in mikro-lokalne podnebne razmere, oblika padavin, menjavata se sneg in dež, razporeditev padavin in osončenost škrapelj.

\footnotetext{
${ }^{1}$ Karst Research Institute, ZRC SAZU, Titov trg 2, SI-6230 Postojna, Slovenia, e-mail: knez@zrc-sazu.si, slabe@zrc-sazu.si

${ }^{2}$ Yunnan Institute of Geography, Yunnan University, Xuefu Road 20, CN-650223 Kunming,Yunnan, P.R. China,

e-mail: hongliu@ynu.edu.cn
}

Received/Prejeto: 5.11.2009 
and microclimate conditions, the form of precipitation, the alternation of snow and rain, the distribution of precipitation, and the solar exposure of the karren.

Keywords: high mountain karren rock relief, Yulong Snow Mountain, Shika Snow Mountain, Yunnan, China.
Ključne besede: skalni relief visokogorskih škrapelj, Snežna gora žadastega zmaja (Yulong), Shika snežna gora, Yunnan, Kitajska.

\section{INTRODUCTION}

The mountain karren rock relief - the Yulong Snow Mountain limestone pavements above Lijiang and the plateau-like Shika Snow Mountain above Shangri-La - reveals the manner of the formation of the mountain karst surface in the northwestern part of Yunnan at altitudes between 4,000 and $4,600 \mathrm{~m}$. The rock relief is an interweaving primarily of rock forms that occur under the snow, those carved by rainwater, composed rock forms reflecting both factors, and to a lesser extent the traces of subsoil rock formation.
The similarity of rock relief in the two areas leads us to the conclusion that their formation occurred under the same climate conditions with a specific form and amount of precipitation and similar latitudes, altitudes, and exposure to the sun of parts of the karren, and of course, to the question of the impact of the geological base and subglacial and subsoil shaping of the surface and the karren.

\section{GEOGRAPHICAL AND GEOLOGICAL DESCRIPTION}

\section{YULONG SNOW MOUNTAIN}

The Yulong Snow Mountain $(5,596 \mathrm{~m})$ is part of the mountain chain that surrounds the high Tibetan plateau in the southeast. The Yangtze River acts as a border between the two. The plateau-like Shika Snow Mountain

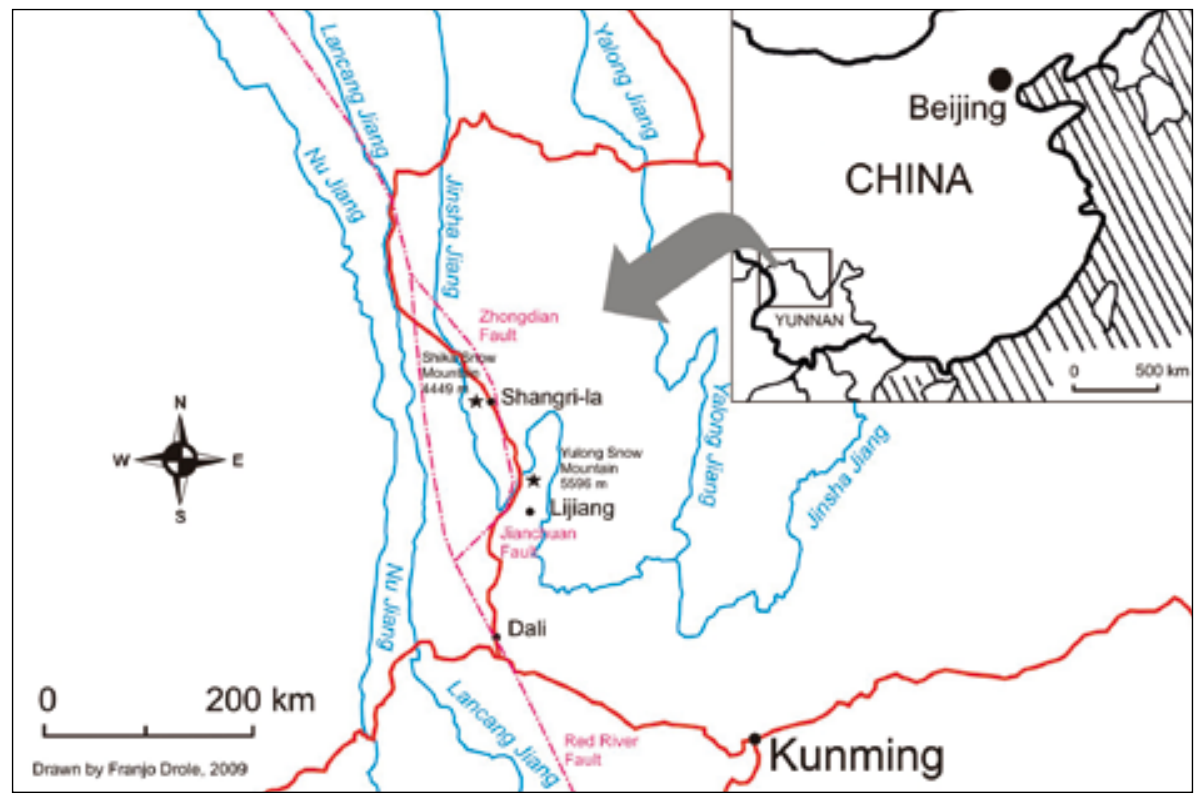

Fig. 1: The position of mountains.

Sl. 1: Položaj gora.
$(4,449 \mathrm{~m})$ above Shangri-La lies in the southeastern part of the Tibetan plateau (Fig. 1). The first mountain lies at $27^{\circ} 06^{\prime \prime}$ latitude and $100^{\circ} 12^{\prime \prime}$ longitude, and the second at $27^{\circ} 47^{\prime \prime}$ latitude and $99^{\circ} 33^{\prime \prime}$ longitude. The first mountain receives $500 \mathrm{~mm}$ of precipitation and the second some-

thing above $600 \mathrm{~mm}$ per year in the form of snow and rain.

On the southern slope of Yulong Snow Mountain karren with distinctive rock relief formed below the conical peaks along the gently sloping section beside the glacier with the southernmost location in the northern hemisphere (Fig. 2). The glacier shaped the mountain slope into cones with stepped rock faces of various inclinations, from almost horizontal terraces to ten-meter-high vertical walls. The glacier retreated thousands of years ago, and the rock relief of the karst surface that formed below the glacier is the direct trace of climate conditions. 
The geological and geomorphological conditions in the wider area of the cities of Shangri-La and Lijiang are very complex, largely due to intensively active tectonic and seismotectonic activity (Yunnan Geological Bureau 1977; Allen et al. 1984; Wang et al. 1998; Wang \& Burchfield 2000; Burchfield \& Wang 2003; Šebela \& Kogovšek 2006). The right lateral displacement Red River Fault lies some $50 \mathrm{~km}$ east of the study area, running

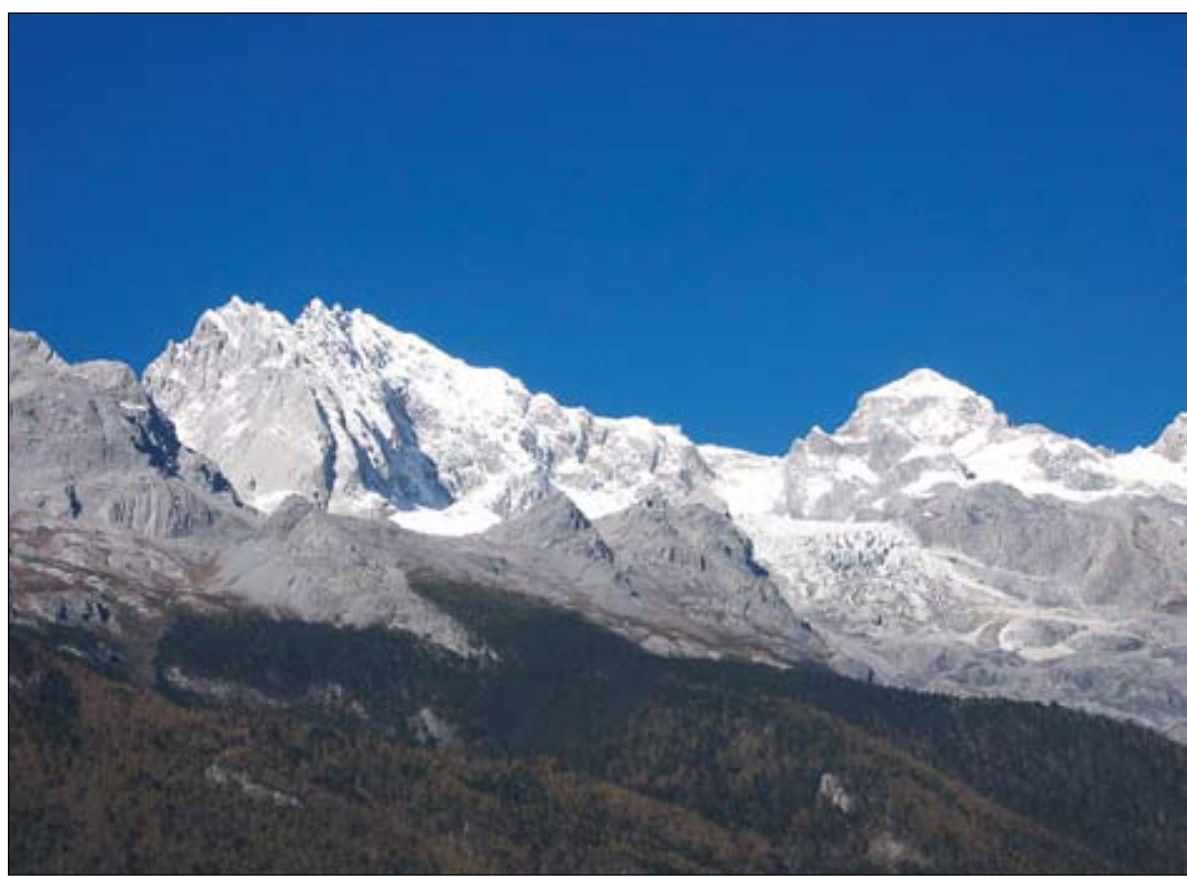

Fig. 2: Yulong Snow Mountain with most southern glacier on northern hemisphere (photo: T. Slabe).

Sl. 2: Snežna gora žadastega zmaja z najbolj južno ležečim ledenikom na severni polobli (foto: T. Slabe).

along the Mekong River to the city of Dali, and to the south we can follow it along the Red River and across Hanoi where it continues to the South China Sea. The Red River Fault Zone is one of the most important fault zones and geological discontinuities in China. During the last geological periods (Tertiary), the movement of the plates beside the zone has measured up to $8 \mathrm{~mm} / \mathrm{a}$ (Wang et al. 1998).

Some $80 \mathrm{~km}$ north of the city of Dali the Jianchuan Fault joins the Red River Fault or branches from it, running north toward the city of Lijiang and the Yulong Snow Mountain where it joins the Zhongdian Fault. The northern end of the Jianchuan Fault enters the Yangtze River valley and is most probably the reason for the first sharp bend of the Yangtze River back toward the north. For some $30 \mathrm{~km}$ the left lateral fault continues to run under the riverbed. Further proof of the active left lateral character of the fault lies in the left bends of numerous tributaries along the western side of the river to the south and across alluvial deltas alongside the eastern part of the river to the north. The entire area is heavily fractured by a number of faults running northwest-southeast and north-south.

In the study area we observed various types of rock, from igneous and metamorphic to sedimentary. Given the geomorphology of the basin in the area of the city of Lijiang, the depression is considered to be of the pullapart origin. At the contacts of branched left lateral faults in particular, the original relief has been completely changed by karst processes. This is also an important contact between Permian basalts and Triassic limestones and clastic rocks.

The Yulong Snow Mountain massif forms the highest section of the Dali High Plateau and is the highest mountain range in this part of Tibet. Erosion during the Pliocene lowered the southern part of the mountain range to altitudes around 3,000 meters. The northwest part of the massif is composed of extensive complexes of metamorphic rock that comprise the central core of the anticline that runs in a north-south direction. The substantial erosion of the rock core of the anticline was influenced by the numerous minor faults located at the edge of the massif. Holocene rocks are frequently dissected by fresh fault scarps. On landslide slopes we also observe numerous blocks of Paleozoic rock sliding downward to the Lijiang basin. This too indicates active tectonics. The Yulong Snow Mountain massif area also includes a number of deep canyons, of which the Tiger Leaping Gorge with more than 3,500 m is the deepest.

The central part of the Yulong Snow Mountain is composed mostly of Carboniferous grey limestone, oolitic limestone with chert nodules, conglomerates, and marble. These rocks are surrounded by Devonian slates interlined with crystalline limestone, dolomite, and marble. In places we also observed dolomitized limestone. The northern part of the mountain is composed of sericite quartz schists. In the east the foot- 
hills of the mountain are composed of Holocene sediments and Permian breccias basalt and limestone, as well as Devonian tuffite. Along with Permian basalt, the southern and western foothills are also composed of grey limestone and dolomitic and argillaceous limestone.

\section{SHIKA SNOW MOUNTAIN}

The broad peak of the plateau-like Shika Snow Mountain (Fig. 3) is dissected into numerous rounded peaks. The highest peaks tower several $100 \mathrm{~m}$ high, and some have steep walls. Between them are large dolines and oblong dells. Their bottoms are dotted with sub-snow

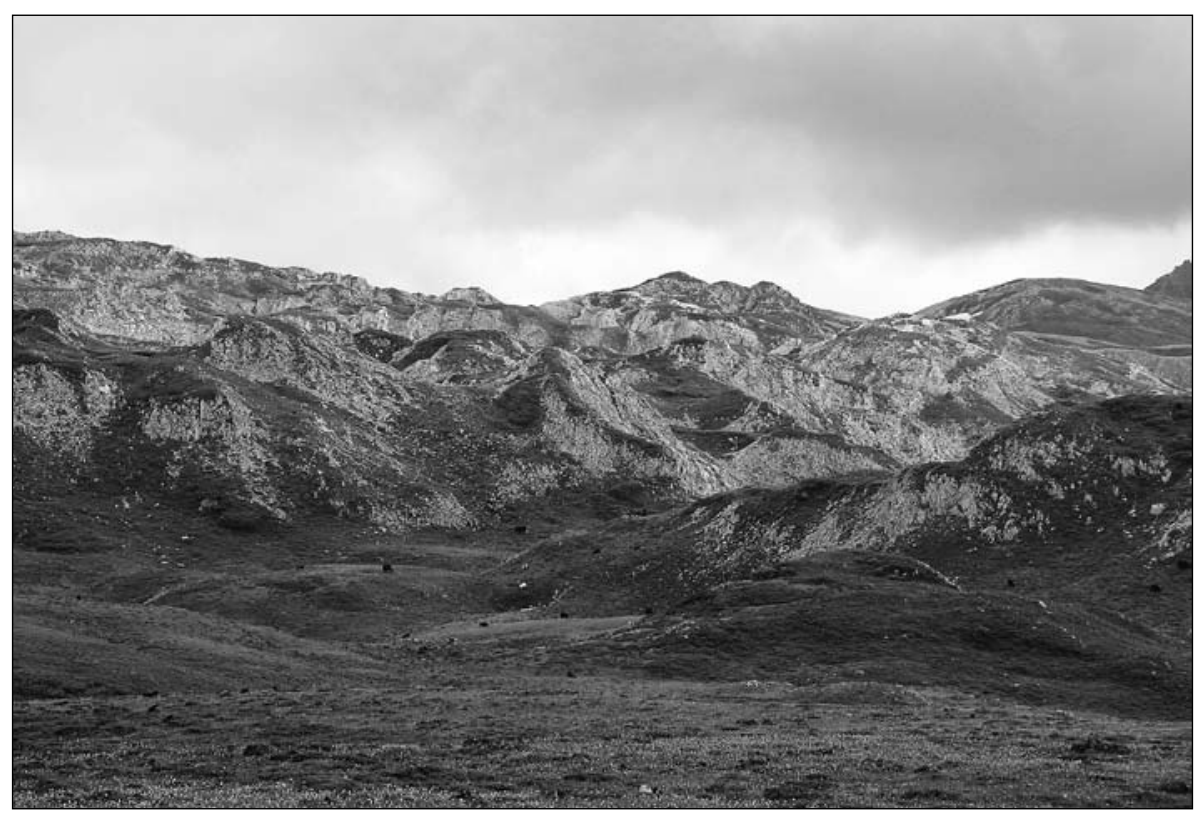

Fig. 3: Shika Snow Mountain (photo: T. Slabe).

Sl. 3: Snežna gora Shika (foto: T. Slabe).

kettles. On the parts of the surface developing on noncarbonate rocks, the waters flow in smaller streams. This led to the formation of various forms of contact karst and polje-like valley systems. Their bottoms lie on noncarbonate rocks and there are sinks at the contact with carbonate rock.

Part of the surface is covered by large pieces of angular gravel, the consequence of fractured rock and its distinctive weathering in harsh climatic conditions, and part of the surface, particularly the lower part, is overgrown. Rock relief is clearly visible on larger rock masses such as karren and on the walls of the rounded peaks. All these factors and the characteristic features of the karst surface make it possible to understand the current formation of the karst surface in the southeastern part of Tibet.

The Shika Snow Mountain is geologically very diverse, particularly the tectonic structure. West of the
Red River Fault and north of Shangri La, the Zhongdian Fault (Chen et al. 1985; Wang et al. 1998; Šebela \& Kogovšek 2006) running across the Shika Snow Mountain massif branches away toward the south and continues in a semicircle toward the south some $10 \mathrm{~km}$ west of Yulong Snow Mountain. Sinistral horizontal movements in the active Zhongdian Fault exist. The fault runs in a northwest-southeast or north-south direction and in this section parallel to the Yangtze River. South of the city of Dali the fault expands into a wider fault zone. The fault can be followed from the north through the city of Shangri-La and the Xiao Zhongdian basins to its contact with the Jianchuan Fault. The central fault is accompanied by numerous weaker parallel faults running across the central fault to form a fault zone.

In the wider area of the Zhongdian Fault between the city of Shangri-La and the Yangtze River, we observe numerous tectonic depressions that developed in carbonate as well as noncarbonate rock. Atypical composite karst poljes are a dominant feature. Depressions in predominantly Triassic carbonate rock were intensively reshaped by karst and lacustrine processes. Because the basins in the Shangri-La area lie entirely at the morphological edge of the Tibetan plateau, it is predicted that the abundant canyon rivers running toward the Yangtze River will soon destroy them (Wang et al. 1998).

A 30 to $35 \mathrm{~km}$ slip of the two blocks has been identified along the fault. The slip probably occurred during the Cenozoic.

Numerous thermal springs located along the fault indicate current very active tectonic activity. The thermal water in some springs reaches almost $70^{\circ} \mathrm{C}$ (Šebela $\&$ Kogovšek 2006). Numerous springs also display greatly increased mineralization and here the waters deposit part of the dissolved substances, usually in the form of travertine.

The area of the mountain peak is composed of Middle Triassic grey limestone and dolomite limestone of the Shanglan Group. The lithological group of Shanglan rock is $2,500 \mathrm{~m}$ thick and its lower part is 
composed of dark grey limestone and marly limestone. Microcrystalline schists and slates occur laterally. The Middle Triassic rocks at the lower elevations are surrounded by Lower Triassic mudstone, sandstone, limestone, and conglomerates of the Bulun Group more than $1 \mathrm{~km}$ thick. Toward the west and north we find mostly Carboniferous crystalline limestone and Devo- nian bituminous limestone. The southern slopes of the mountain are mostly composed of slates, metamorphic sandstone, and conglomerates, which in places are intercalated with crystalline limestone. The eastern foothills end in the valley of the Shangri-La city, which is covered by Quaternary sediments.

\section{ROCK RELIEF OF MOUNTAIN KARREN}

The rock relief is composed of three dominant types of rock forms that are intertwined in equal proportions. The first type are rock forms that develop under snow, the second type is formed by rainwater (one of these

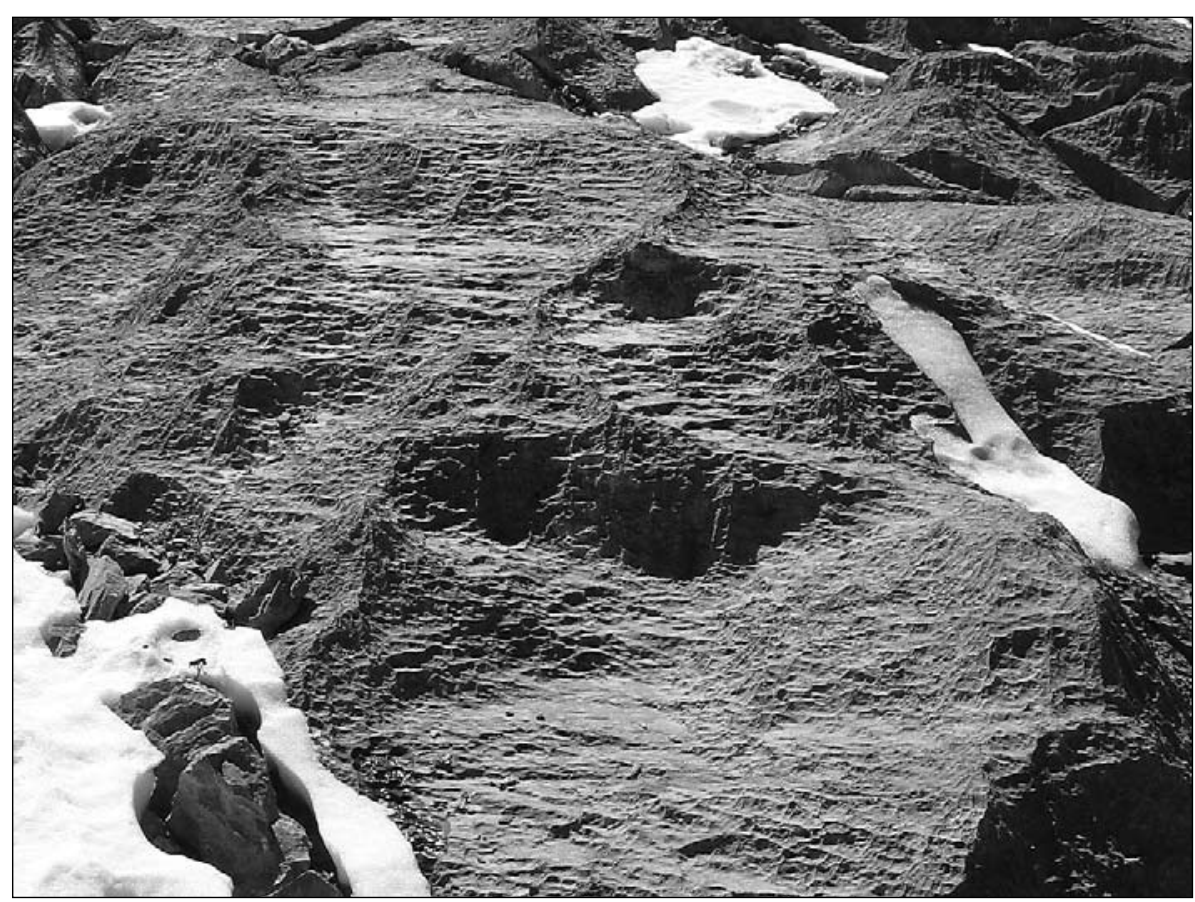

Fig. 4: Sub-snow stepped surface (width of the view in the middle is $3 \mathrm{~m}$ ); (photo: M. Slabe). Sl. 4: Podsnežna stopničasta površina (širina prizora je $3 \mathrm{~m}$ ); (foto: M. Slabe).

er sections of rock that has been covered by snow for a longer period, that is, on the upper surfaces of karren and their walls. It is a network of centimeter steps. Somewhat larger steps are found on the more gently sloping parts of the surface. The tread of the steps is more or less horizontal or slightly slanting in the direction of the slope of the rock surface. They are often combined in a series across the slope, in particular in channel-like depressions dissecting the stepped rock surface and can stretch across the entire width (Fig. 5). The stepped surface can be several meters wide and relatively evenly formed across the entire rock or dissected by channel-like depressions in which larger quantities of water collect and larger steps. As a rule, they form on the lower parts of dissected karren surfaces that remain under snow for a longer period while higher up they can be dissected by rain flutes (Lundberg \& Ginés 2009). Stepped surfaces are mainly charac-

two prevails as the dominant factor in shaping the rock), and the third type is composed rock forms. All three types display traces of the two most efficient factors of their formation.

\section{SUB-SNOW ROCK FORMS}

In both mountain areas they are represented by a stepped surface and individual larger horseshoe-shaped steps, sub-snow channels, and sub-snow notches. A stepped surface (Figs. 4,5) develops on both gentler and steep- teristic of sunless sites or surfaces where more snow accumulates. They develop due to the relatively even creeping of water trickling from the melting snow across the entire rock surface.

Singly or in places linked in a series, larger semicircular steps and straight steps dissect the rock (Mietto \& Sauro 1989, 344; Kunaver 2009; Tóth 2007, 2009; Veress 2009a). They differ in size from the small steps linked in a network. Both types have a characteristic steep inflow wall and an almost horizontal tread. Semicircular steps 


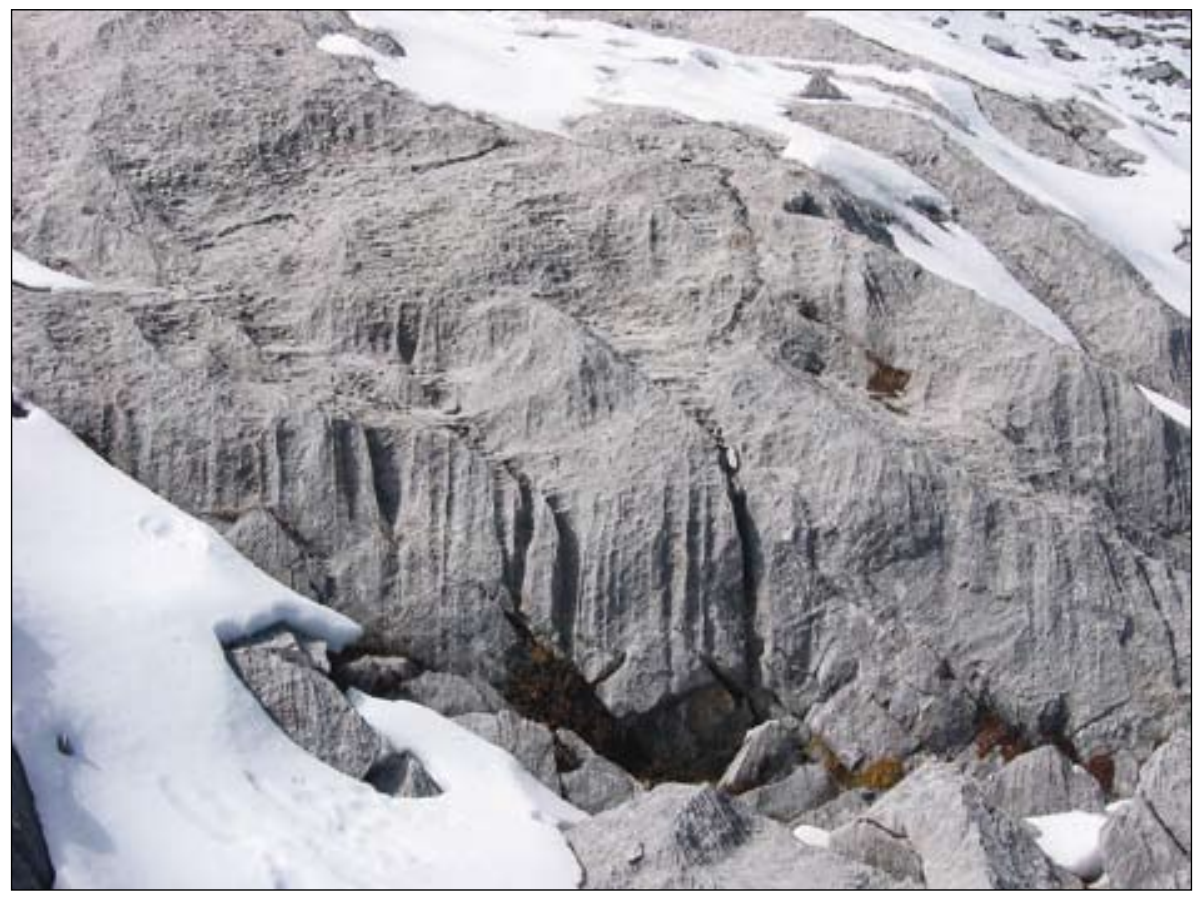

Fig. 5: Sub-snow stepped surface, channels and flutes (photo: M. Slabe).

Sl. 5: Podsnežna stopničasta površina, žlebovi in žlebiči (foto: M. Slabe).

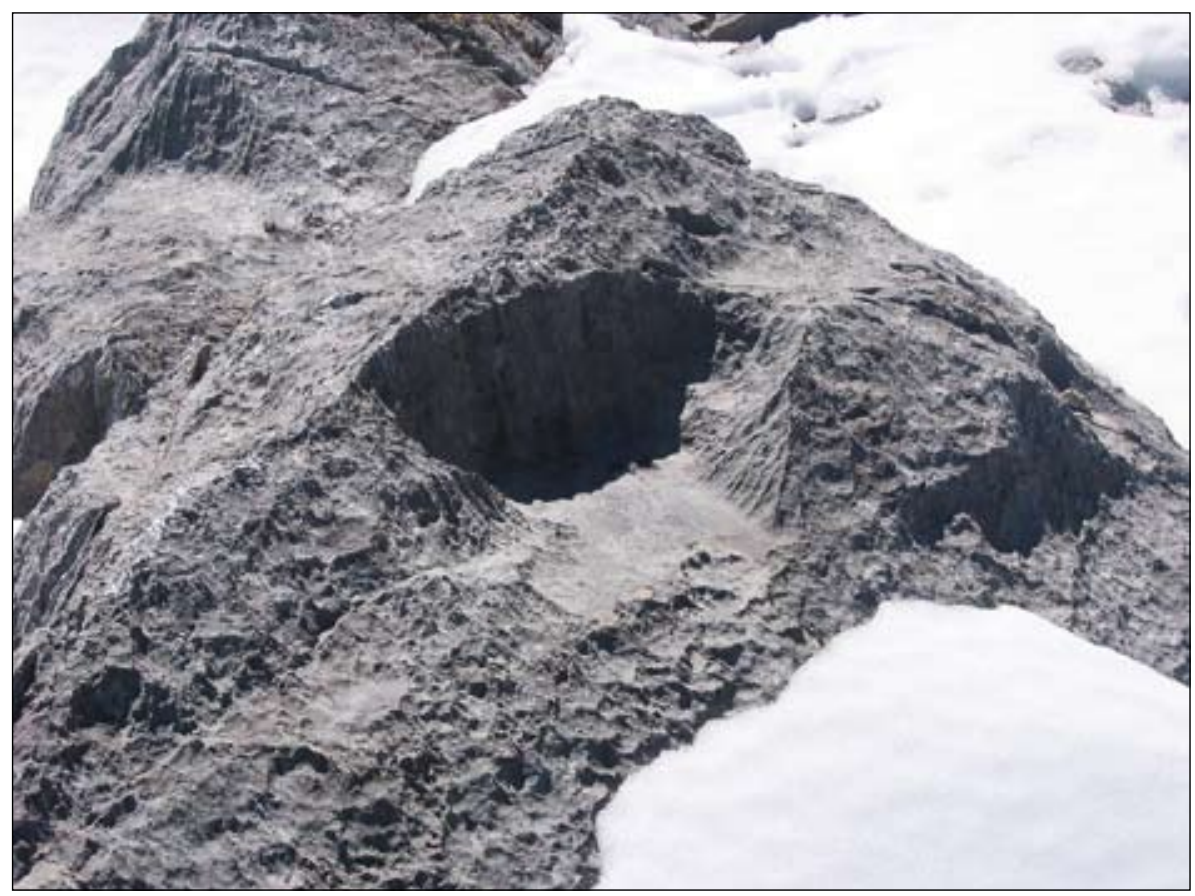

Fig. 6: Semicircular step (photo: M. Slabe).

Sl. 6: Podsnežna polkrožna stopnica (foto: M. Slabe).

(Figs. 4, 6) occur in various sizes and shapes. The diameters of the largest steps exceed $1 \mathrm{~m}$. Their inflow walls range from a few centimeters to more than $1 \mathrm{~m}$ high.
Some are wide open while others are two-thirds surrounded by steep bordering walls. As a rule, their tread is horizontal or slightly slanting and in places deepened by cups. Snow remains longest on flat surfaces, deepening the steps and widening them backwards and laterally. Where sub-snow rock formations dominate, the steps have overhanging inflow walls. Very distinctive steps of this kind developed on the fractured rock of the Shika Snow Mountain (Figs. 4, 7). Runoff channels developed below the larger sub-snow steps. The width of flat steps reaches dozens of centimeters. On steep surfaces (Fig. 8) their inflow walls can be more than $1 \mathrm{~m}$ in height, while on gently sloping parts of the rock where they are located one above the other, the inflow wall is only a few centimeters high. In most cases, their tread is smooth. In places we can see that they formed from a lengthwise connection of a series of semicircular steps.

Small steps that protrude from the walls were formed by the merging of sub-snow steps located one above the other on steep walls (Fig. 8). The upper more or less horizontal tread is part of the tread of the upper semicircular step, which is continuously narrowed by the growth of the lower steps, and the walls are the upper part of the walls of the lower two steps.

There are several types of sub-snow channels as well (Tóth 2007; Veress 2009a, b). We have already mentioned wide and stepped channels that dissect larger stepped surfaces (Fig. 5). They are the trace of water trickles uniting 


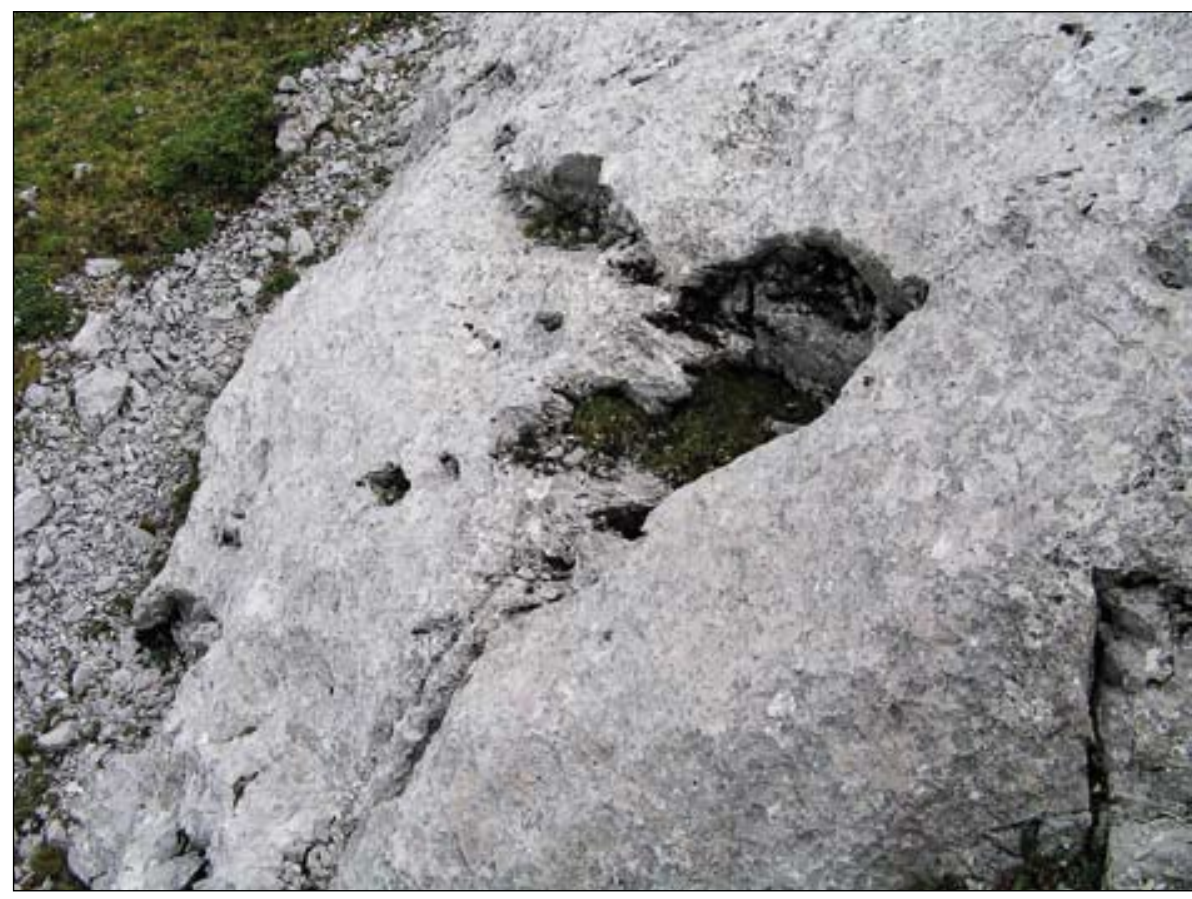

Fig. 7: Large sub-snow step (width of the view in the middle is $3.5 \mathrm{~m}$ ); (photo: M. Slabe). Sl. 7: Velika podsnežna stopnica (širina prizora je $3.5 \mathrm{~m}$ ); (foto: M. Slabe).

that as a rule flow relatively evenly over the entire stepped surface. In the two mountain areas, meandering sub-snow channels (Veress 2009c), often a characteristic form on gently sloping rock surfaces shaped under snow, are a relatively rare feature. In places, smaller slightly meandering channels that form mostly due to melting at higher parts of the surface, dissect gently sloping stepped rock. Vertical channels with semicircular cross sections measuring one decimeter in diameter formed on the walls of rock blocks that are the edges of fissures completely covered by snow for a longer period. On steep larger walls the channels (Fig. 9) formed side by side. Water from ledges flows in them. They are further shaped by

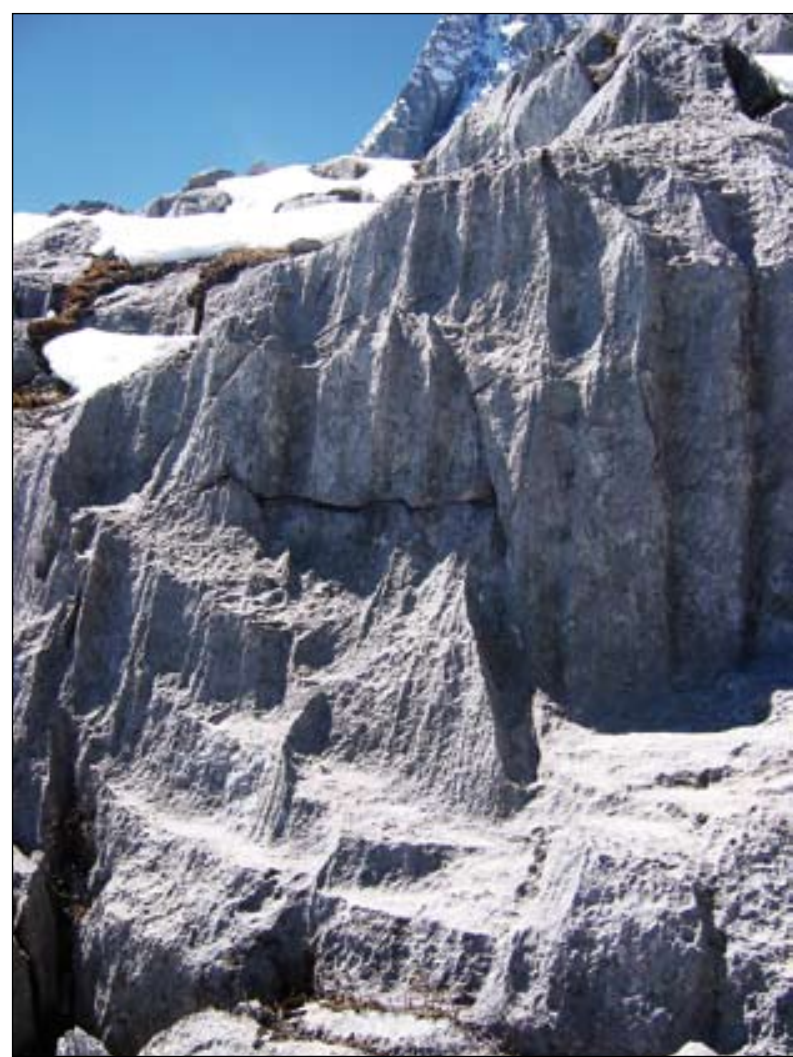

Fig. 8: Sub-snow stepped vertical wall (photo: M. Slabe). Sl. 8: Podsnežna stopničasta navpična stena (foto: M. Slabe). rainwater and are one of the most distinctive composed rock forms in both mountain karren areas. Sub-snow widenings measuring $1 \mathrm{~m}$ in diameter of parts of the channels on the lower parts of the walls are frequent to where the snow blanket reaches. Under the snow longitudinal semicircular or semi-pocket notches (Fig. 10) also form. They reflect the depth of the relatively long-lasting snow cover that surrounds the lower parts of the walls.

\section{ROCK FORMS CARVED BY RAINWATER}

They are mainly flutes (Lundberg \& Ginés 2009), solution pans, and wall channels. They are found on surfaces where rainwater is the dominant factor of rock formation and thus remain covered by snow for a shorter period. These are mainly sunny surfaces that are often completely covered by flutes (Fig. 11). The boundary between the sunny and sunless sides of the karren on the Shika Snow Mountain is distinct (Fig. 12). On the sunless side the flutes are typically only found just below the top. The flutes as a rule also cover the tops and the ridges of rock (Fig. 13) where sub-snow rock forms dominate as well as on sharp bends and ridges protruding from stepped sub-snow surfaces and on the lower edges of rock blocks. They are more frequent on the steeper sections of rock. They are therefore the parts of the karren that were first to become denuded or were originally covered by snow only to a lesser degree. Flutes also dissect the walls of composed rock forms. On steep walls the dominant rock forms are channels con- 

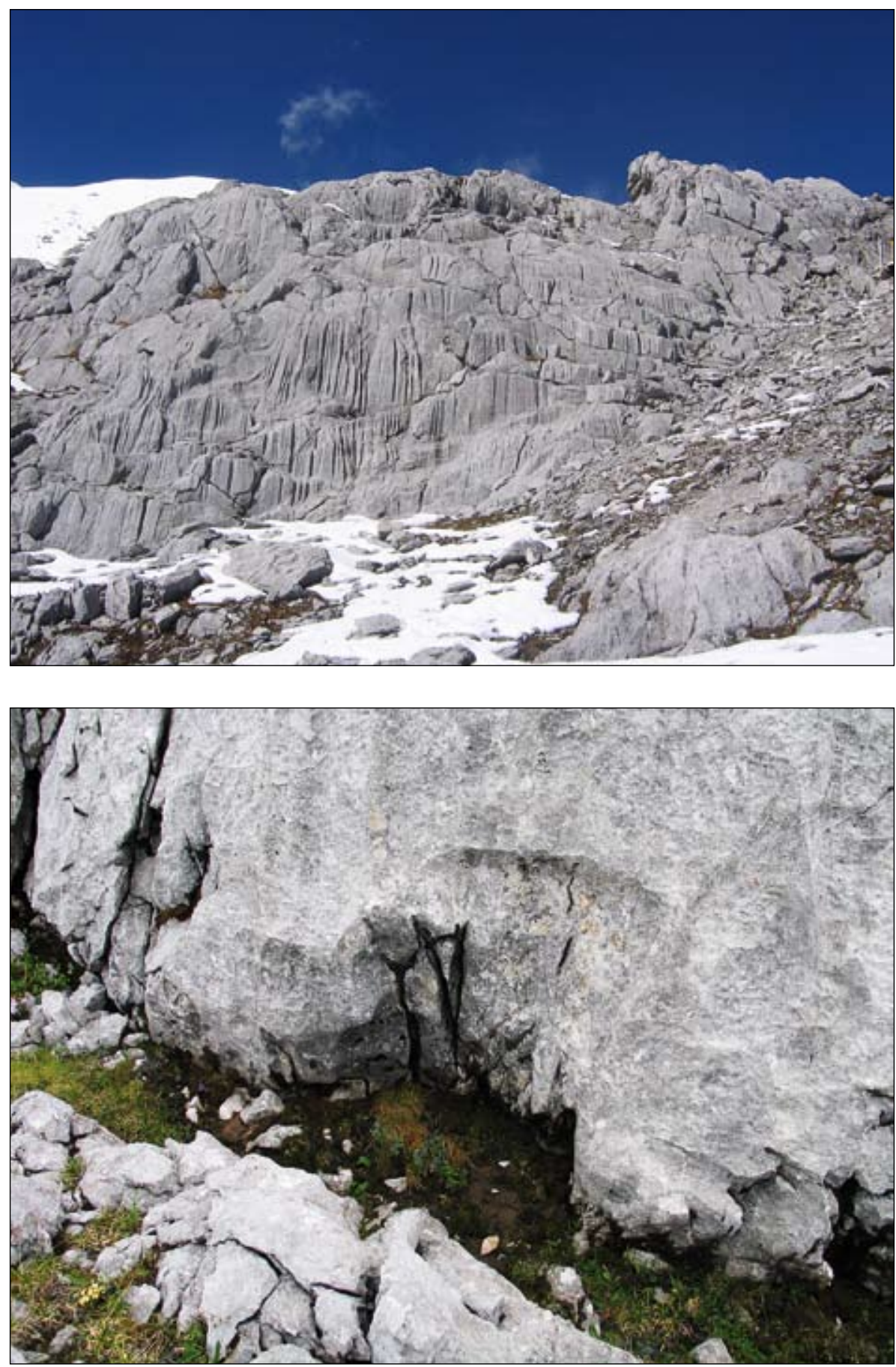

Fig. 9: Wall channels bellow snow ledges (photo: M. Slabe).

Sl. 9: Stenski žlebovi pod snežnimi policami (foto: M. Slabe).
Fig. 10: Sub-snow semi-pocket notch (width of the view in the middle is $3.5 \mathrm{~m}$ ); (photo:

M. Slabe).

Sl. 10: Podsnežna polkotličasta zajeda (širina prizora je $3.5 \mathrm{~m}$ ); (foto: M. Slabe). nected in a network (Veress 2009b). Rain scallops (Slabe 1998,62 ) form on overhanging walls as a trace of water creeping evenly down a larger rock surface.

\section{SUBSOIL ROCK}

Subsoil rock (Fig. 14) forms (Slabe \& Knez 2004; Slabe 2009) are characteristic of the Shika Snow Mountain, which to a large extent is overgrown with moss, grass, and bush rhododendron, while on the Yulong Snow Mountain moss and grass only cover fissures to a lesser extent. The larger rock surfaces on the rounded peaks and steep walls of the plateau-like peak of the Shika Snow Mountain are bare. Smaller subsoil channels form on the walls of the karren at the contact with a thin layer of soil. Water flowing from the overgrown tops, wall ledges, and notches creates larger wall channels 

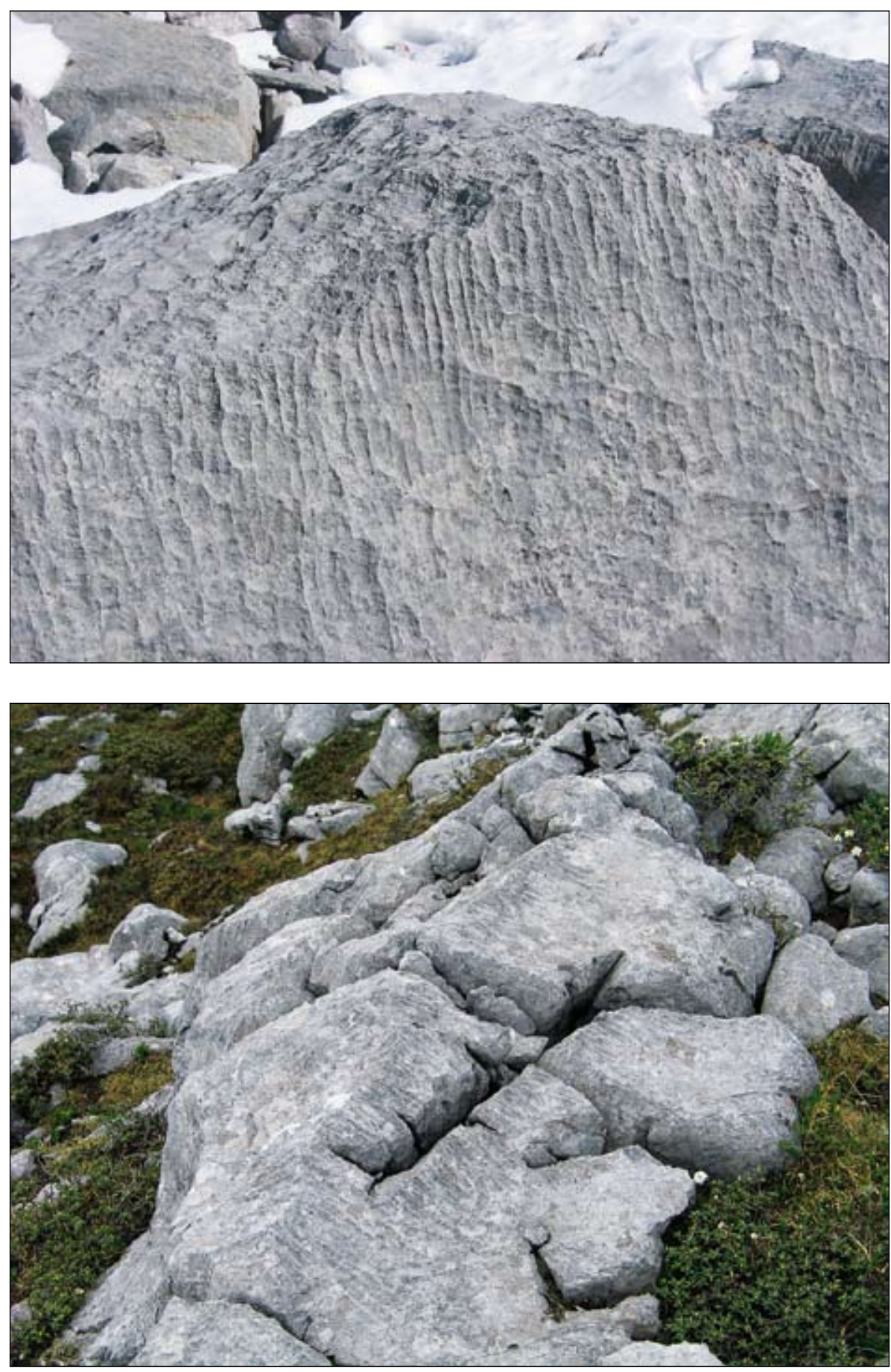

Fig. 11: Flutes on sunny side and flat sub-snow surface on sunless side (photo: $M$. Slabe).

Sl. 11: Žlebiči na strmi prisojni strani in položna ter osojna podsnežna površina (foto: M. Slabe).
Fig. 12: Flutes on sunny side and sunless sub-snow surface (photo: M. Slabe).

Sl. 12: Žlebiči na prisojni strani in osojna podsnežna površina (foto: M. Slabe).
(Fig. 15). Their formation is also influenced by rainwater and where they are filled with snow by corrosion as well at the contact with melting snow. We can classify them among composed rock forms. The rock is largely covered by a thin layer of lichen, which is distinctive in white and dark grey patches. Under the lichen, the rock is smooth and rounded. The fine biocorrosive erosion of the rock is significant.

\section{COMPOSED ROCK FORMS}

In the formation of rock forms, the rock is primarily affected by rain and snow, by water trickling from overgrown snow-covered ledges, and at the contact with soil by water percolating through the soil. At least two of these factors are evident in composed rock forms that have worked on the rock alternatively or consecutively. Their traces intertwine in various proportions, but one of 


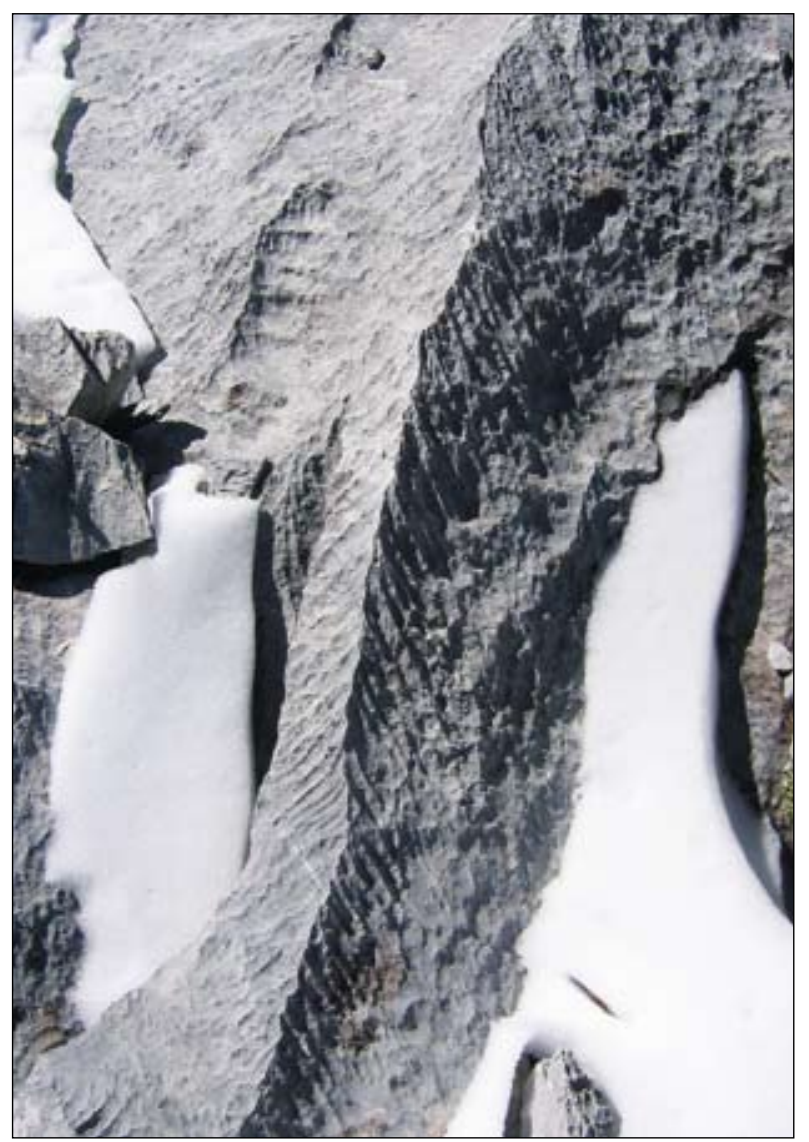

Fig. 13: The flutes on the top of the ridge (photo: M. Slabe). Sl. 13: Žlebiči na skalnem razu (foto: $M$. Slabe). them often dominates in characteristic parts of the rock relief or in rock forms. Biocorrosion in particular affects the fine formation of the surfaces of rock forms and prepares the rock for other processes.

Larger sub-snow steps or series of sub-snow steps clearly show their further shaping by rainwater. Their upper, more or less vertical walls are indented by flutes, and if a sharp bend is located below them, flutes dissect this as well (Fig. 5). Flutes are also found on the walls of larger sub-snow channels. The bottoms of steps and channels are covered by snow for a longer period and the two rock forms develop below it; however, the walls above them are exposed to rainwater and thus become bare more rapidly. Wall channels are one of the most distinct composed rock forms; they form due to water trickling from the ledges that are periodically covered by snow (Fig. 9) or by vegetation and soil (Fig. 15; Veress 2009d). They can be many meters in length and their diameters can be measured in decimeters. They are further shaped by rainwater in direct contact with the rock surface, and in their lower parts or where the snow blanket extends above ledges, they widen under the snow to reach one meter in diameter. When the water cuts deeper into the bend of the rock, their upper parts often begin with funnel-like mouths whose walls are dissected by flutes. Similar funnel-shaped mouths (Fig. 5) also form on sharp bends between a gently sloping upper rock surface that is dissected by steps and a vertical wall below it. Often, the inside of a stepped surface is dissected into wide, stepped channel-like depressions where water collects before

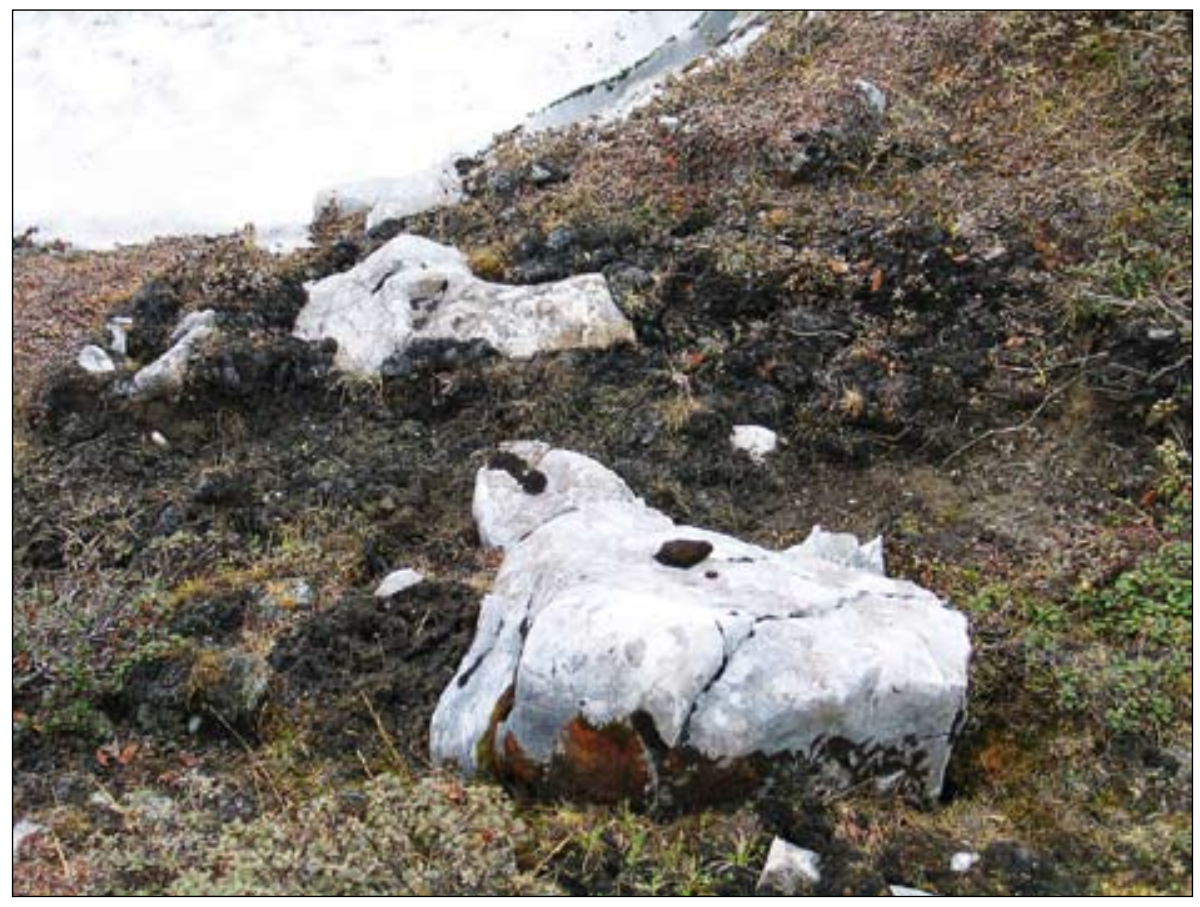

Fig. 14: Subsoil rounded rock (width of the view in the middle is $3 \mathrm{~m}$ ); (photo: M. Slabe).

Sl. 14: Podtalno zaobljena skala (širina prizora je $3 \mathrm{~m}$ ); (foto: M. Slabe). 


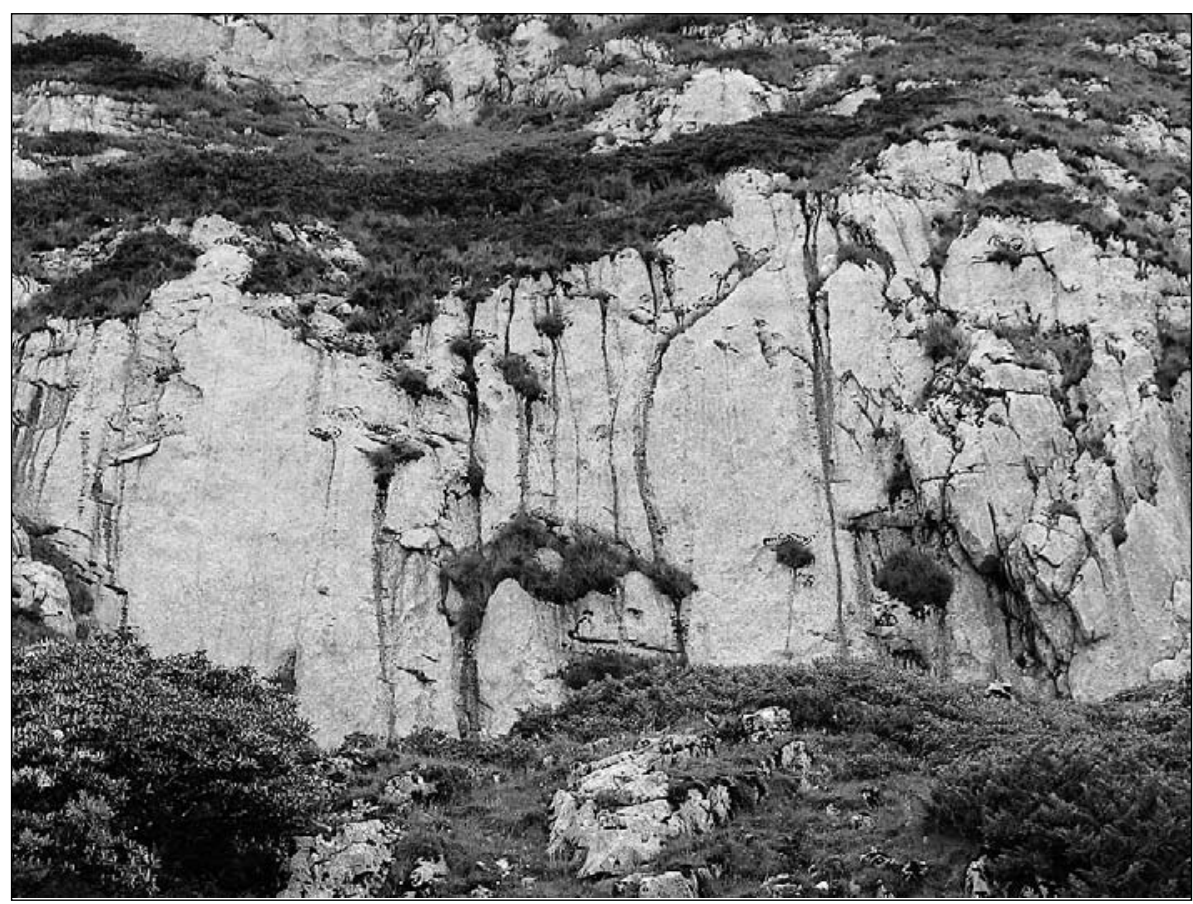

Fig. 15: Wall channels bellow ledges covered by vegetation (width of the view in the middle is $40 \mathrm{~m}$ ); (photo: M. Slabe).

Sl. 15: Stenski žlebovi pod poraslimi policami (širina prizora je $40 \mathrm{~m}$ ); (foto: M. Slabe). running off down the wall and even more distinctly cutting into the bend. The walls of deeper funnel-like mouths are dissected by flutes. Snow only remains for a longer period at the bottom of channels and mouths. Bare surfaces, of course, are further shaped by rainwater.

Composed rock forms can also include reshaped subsoil rock forms and glacially polished rock. The bare rock is shaped by water from melting snow and rainwater. The smooth and rounded subsoil surface and subsoil channels, as well as the surface polished under a glacier, are reshaped by sub-snow and rain rock forms and the traces of water creeping down vertical and overhanging rock surfaces.

\section{CONCLUSION}

Two dominant factors, snow and rain, decisively influence the formation of the majority of rock forms; in places, particularly on the Shika Snow Mountain, two additional factors are subsoil corrosion and water trickling from overgrown wall ledges. Biocorrosive erosion is important for the fine dissection of the rock. The dominance of one of the factors causes the formation of more or less uniform sub-snow or rain rock forms; other agents affect the rock to a lesser degree. Composed rock forms display traces of several factors that alternate or follow one another as in the case of denuded subsoil forms. The channels below snow-covered or overgrown ledges are the trace of water trickling down the walls from the ledges, rainwater falling directly on them, and, in the lower parts, long-term snow cover.

Sub-snow rock forms dominate in places where the rock has been covered by snow for a longer period. These are primarily the gently sloping sunless parts of the karren, the lower parts or lower walls of karren, and fissures. Gently sloping sunless parts of the karren are often dissected in various ways so there are sub-snow forms on their lower parts and rock forms carved by rainwater on the higher parts, peaks, and ridges. Rain rock forms dominate on sunny surfaces and parts of the rock that are steep, located higher above the floor, and covered by only a thin layer of snow. Frequently, the same surface displays rain rock forms typical of steep walls and subsnow rock forms typical of gently sloping parts of the rock side by side.

An intertwining of distinct factors-primarily rain and snow that alternate and dominate in specific parts, to a lesser degree the reshaping of old mainly subsoil rock forms, and water trickling from overgrown or snow-covered ledges-dictates the formation of a unique relief characteristic of these conditions. The relief and individual rock forms are also influenced by the fissuring and the recrystallization of rock of the Shika Snow Mountain. The rock masses on the Yulong Snow Mountain are larger and its rock forms have more regular shapes. On the Shika Snow Mountain, rock recrystallization has an important influence on the rock forms, causing fine diversities and often jagged edges of rock forms. By this feature of rock forms and the frequent and originally subsoil rock formation on the Shika Snow Mountain we can distinguish the two described areas of mountain karren. 
In both mountain areas, the basic characteristics are the same and unique. The rock relief of the mountain karren described in this paper is predominantly dictated by the wider climate and microclimate conditions, the form of precipitation, the alternation of snow and rain, the distribution of precipitation (the majority of precipitation falls in the rainy period between May and Septem- ber so snow is less abundant), the solar exposure of the karren and consequently persistence of snow cover on the rock surface on different inclination. The relatively low latitude and its characteristic climate conditions therefore prevail over the high altitude, which at higher latitudes is characterized mostly by sub-glacier and subsoil rock relief (Kunaver 2009; Tóth 2007, 2009).

\section{REFERENCES}

Allen, C.R., Gillespie, A.R., Han, Y., Sieh, K.E., Zhang, B. \& C. Zhu, 1984: Red river and associated Yunnan province, China: Quaternary geology, slip rates, and seizmic hazard.- Geological Society of America Bulletin, 95, 686-700.

Burchfield, B.C. \& E. Wang, 2003: Northwest-trending middle Cenozoic left-lateral faults in southern Yunnan, China, and their tectonic significance.- Journal of Structural Geology, 25, 781-792.

Chen, Y., Xue, G., Luo, W., Liu, Z. \& C. Zhou, 1985: Regional geological survey report of People's Republic of China, sheet Zhongdian 1 : 200 000.- Kunming.

Kunaver, J., 2009: Corrosion terraces, a megaausgleichfläche or a specific landform of bare glaciokarst.- In: Ginés, A. et al. (eds.), Karst Rock Features, Karren Sculpturing. ZRC Publishing, pp. 161-168, Postojna -Ljubljana.

Lundberg, J. \& A. Ginés, 2009: Rillenkarren.- In: Ginés, A. et al. (eds.), Karst Rock Features, Karren Sculpturing. ZRC Publishing, pp. 185-210, Postojna -Ljubljana.

Mietto, P. \& U. Sauro (eds.), 1989: Grotte del Veneto.Federazione Speleologica Veneta, pp. 415.

Slabe, T., 1998: Rock relief of pillars in the Lunan Stone Forest.- In: Chen, X. et al. (eds.), South China Karst I. ZRC Publishing, pp. 51-67, Ljubljana.

Slabe, T., 2009: Karren simulation with plaster of Paris models.- In: Ginés, A. et al. (eds.), Karst Rock Features, Karren Sculpturing. ZRC Publishing, pp. 4754, Postojna -Ljubljana.

Slabe, T. \& M. Knez, 2004: Kraške podtalne skalne oblike [Karst Subsoil Rock Forms].- Annales, series historia naturalis, 14, 259-266.

Šebela, S. \& J. Kogovšek, 2006: Hydrochemic characteristics and tectonic situation of selected springs in central and NW Yunnan Province, China.- Acta carsologica, 35, 1, 23-33.
Tóth, G., 2007: A mérsékeltövi mészkö magashegységek fedetlen karros celláinak osztályozása és fejlődése. Classification and development of bare karren cells in calcareous high mountains. Classification et développement des cellule lapiasées nues alpines.- BDF Természetföldrajzi Tanszék, pp. 116, Szombathely.

Tóth, G., 2009: Karren features in Dachstein mountain.In: Ginés, A. et al. (eds.), Karst Rock Features, Karren Sculpturing. ZRC Publishing, pp. 313-322, Postojna -Ljubljana.

Veress, M., 2009a: Trittkaren.- In: Ginés, A. et al. (eds.), Karst Rock Features, Karren Sculpturing. ZRC Publishing, pp. 151-159, Postojna -Ljubljana.

Veress, M., 2009b: Rinnenkarren.- In: Ginés, A. et al. (eds.), Karst Rock Features, Karren Sculpturing. ZRC Publishing, pp. 211-222, Postojna -Ljubljana.

Veress, M., 2009c: Meanderkarren.- In: Ginés, A. et al. (eds.), Karst Rock Features, Karren Sculpturing. ZRC Publishing, pp. 223-235, Postojna -Ljubljana.

Veress, M., 2009d: Wandkarren.- In: Ginés, A. et al. (eds.), Karst Rock Features, Karren Sculpturing. ZRC Publishing, pp. 237-248, Postojna -Ljubljana.

Wang, E., Burchfield, B.C., Royden, L.H., Chen, L., Chen, J. \& W. Li, 1998: The late Cenozoic Xianshuihe-Xiaojiang, red River, and Dali fault systems of southwestern Sichuan and Central Yunnan, China.Geological Society of America, Special Paper, 327, $1-108$.

Wang, E. \& B.C. Burchfield, 2000: Late Cenozioc to Holocene deformation in southwestern Sichuan and adjacent Yunnan, China, and its role in formation of the southwetern part of Tibetian Plateau.- Geological Society of America, Bulletin, 112, 3, 413-423.

Yunnan Geological Bureau, 1977: Regional geological survey report of People's Republic of China, sheet Lijiang $1: 200$ 000.- Kunming. 